\title{
STUDENTS' PERSPECTIVE AND EXPERIENCE ON THE USE OF ENGLISH AS MEDIUM OF INSTRUCTION IN INTRODUCTION TO BUSINESS CLASS: A QUALITATIVE INTERVIEW STUDY
}

\author{
Novel Doloksaribu ${ }^{1}$, Debora Chaterin Simanjuntak ${ }^{2}$ \\ 1,2 Universitas Advent Indonesia \\ ${ }^{1}$ noveldoloksaribu@gmail.com, ${ }^{2}$ debora.simanjuntak@unai.edu
}

\begin{abstract}
As higher education institutions strive to become increasingly international, English-medium teaching has become a main concern to develop students' English proficiency in preparing them for international competition. Therefore, this study aims to investigate students' perceptions and experience on a program called PEBUC. It is a program devised by the Faculty of Economy at Universitas Advent Indonesia (UNAI) in which the concept is derived from English Medium Instruction (EMI). It is a qualitative interview study, used to assess people's experience, perceptions, behaviors and other aspects. Semistructured interview was implemented to 10 informants who had experienced taking the program. The findings of this study showed two themes emerged on how students perceived the program; those themes are Promote Thinking-learning system and Stimulate Learners' Engagement. Furthermore, there are two themes that characterize the experience of informants on the program; which are, Enhance recognition of English Language and Self-regulated learning. Meanwhile regarding the needs of program development there are two themes emerged: Learning Resources and Analysis on Students' Prerequisites. All themes emerged from obtained sub-themes.
\end{abstract}

Keywords: Business English, EMI, PEBUC, Students' Experience, Students’ Perspective

\section{INTRODUCTION}

In this modern era of globalization, the growth of international business is fast and tight. Knowing English is a mark of superior knowledge that is needed in international business. Therefore, Academic administrators in business institutions are increasingly sensitive to the importance of English proficiency; wherein they become aware that it may support their students' future employment. Rao (cited in Low, 2020) clearly pointed out that having good English proficiency could lead the way to having employment success. In addition, the language of communication in business in English, is the most-used language on the internetcommunicating around the world (Sankar \& Suresh Kumar, 2016). To support this notion, Crichton and Scarino (cited in Benzie, 2010) stated that English proficiency requires a corresponding practice not just seen as skill because the language learning process involves a range of skills to successfully use the language in communicating with others. Simatupang (cited in Lauder, 2008, p.11) added, "although English in Indonesia is not used in society as a medium of communication in official domains, it is still seen as a priority, as the most important of the foreign languages to be taught." Henceforth language programs that uphold the concepts of EMI to support the development of English proficiency have been taken into accounts. $\mathrm{Hu}$ \& Wu (2020) emphasized that programs with English language learning should be based on the role of the language and the understanding of subject content. 
This study is conducted to investigate students' perceptions and experience after taking the PEBUC program. It is a program for business courses, wherein, the lecturers utilize English as the medium of instruction. Students are required to interact with one another in English. This program has been implemented for one and a half years. The main purpose of devising this program is to improve Economic students' English skills on business communication. The focus area of this study is to find out the effectiveness of PEBUC program, students' engagements on English learning, and the development of PEBUC program. In order to attain research objectives, the researchers formulated these research questions: a) How effective is the implementation of the PEBUC program? b) How do students in the PEBUC program engage with English learning? c) What are the things that should be put into consideration in the PEBUC program?

\section{English used as Medium of Instruction}

In many universities English Medium Instruction is widely known as an educational phenomenon whereas many researchers are interested in investigating its learning process (Macaro, 2020). 'The exponential growth of English as a medium of instruction (EMI) in countries where English is either a second or foreign language has been problematized in an ever-growing literature on the subject mainly due to issues of effectiveness and generalizability' (Talaue \& Kim, 2020, p.321). Researchers recently are concerned with the use of English as Medium of Instruction in various courses (Köksal \& Tercan, 2019). According to (Macaro, 2018), English as a Medium of Instruction is the use of English language to teach academic subjects in countries where the first language of the majority of the population is not English. EMI has gained popularity in the world because of the English language becoming a lingua franca (ELF) and also the dominant international language. It is not only because the global business community needs, but already growth in academic publication, globalization, networking, the global market, and the Internet (Tsou \& Kao, 2017). Additionally, Pritasari, Reinaldo, and Watson (2018) said that business and management are areas that concern the global importance of English. Hence there is a strong demand in the education field to provide quality courses where English becomes the medium of instruction. Nevertheless a study conducted by Sari \& Wahyudin (2019) pointed out that using English as a medium of instruction could be a challenge in Indonesia because many large classes have mixed-ability students, in which some students are not actively engaged in the learning process. Consequently, courses that utilize English as a medium of instruction should be aware of this challenge. Teachers must be able to cater the needs of their students. Macaro (2020) added that lecturer in EMI courses should be aware of his students' vocabulary knowledge for the success of the learning process.

\section{The Significance of incorporating English into Business Field}

The lingua franca or a common language of today's business world is English, it empowers communication among business practitioners from different cultural backgrounds. In the business context, the use of English lingua franca (ELF) is connected with the globalization of both business operations and communication technology. Recently, members and employees in company networks and partnerships had to be able to use ELF professionally, in other words, they needed to work in English (Kankaanranta, 2008). According to Peters (2014), English has widened as day-to-day communication. Kankaanranta \& Louhiala-Salminen (2010) observed that mother tongue and English is needed for globally operating business professionals. Bargiela-Chiappini \& Zhang (2013) stated, 'Business English has become an umbrella concept that incorporates a range of subjects deemed to be necessary for the development of well- 
rounded specialists trained to satisfy the needs of the fastest growing economic power in the world.'

\section{THEORETICAL BASES}

This study is based on Language learning theory of Crawshaw (1984); on how teachers should be able to understand their learners' ability in applying a mixture of intuitive and conscious process in receiving information about the language they learn. Utilizing this theory as the research foundation can help researchers to see the learning process through different dimensions. Other than that, tying the theory of language learning with the theory of Krashen: Communicative Language Teaching and Natural Approach would be research-wise. The goal of this theory is to view how learners use their abilities communicating the target language (Koondhar et al., 2018). These two theories helped researchers to shape, explain, predict and understand the research problems within the existing boundaries which may somehow support this study.

\section{METHOD}

Qualitative study allows flexibility and subjectivity that develop and enhance given study; in investigating informants' experience and perceptions, qualitative method is suitable because it helps researchers to explore deeper (Simmons, 2016). This study utilizes qualitative interview study which is commonly used to explore people's experience and perceptions. According to DeMarrais (2004), "qualitative interview approaches to research can be stimulating and rewarding experiences for both researchers and participants."

\section{Research Stages}

In this study, the researchers presented three stages to reach the aim of the study. In the first stage, the researcher collected the data from Administrative and Academic Bureaus in UNAI to search suitable informants for the study. In the second stage, the researcher asked the adviser to make a consent letter that would be given to the Dean Faculty of Economy UNAI. After getting approval, in the third stage, the researchers asked interviewees' permission to participate in this study and keep their records confidential.

\section{Research Informants}

The sampling technique of this study is purposive sampling because it focuses on particular characteristics which enable the researchers to obtain answers of the research questions (Palinkas et al., 2015). In this study, the researchers chose key informants that could provide relevant information to the study. Therefore, the followings are the inclusion criteria to recruit informants: a) Economics students who have taken Introduction to Business Class - a basic and compulsory course in the first semester for first year students; b) Students who have English National Exam scores were in senior high school below 70; c) Students who have average result after taking the course.

\section{Research Instruments}

The instrument of this research is an interview using a semi-structured interview. It contained seventeen open-ended questions concerning the students' perspective and experience about the PEBUC program. The researcher and the informants were engaged in a formal interview. The interview protocol included opened-ended questions, allowing for engagement between the interviewer and the key informants as well as giving freedom to the key informants to express 
their opinions and perception related to the topic. The interview was used and recorded via Zoom and call. The interview sessions for each participant lasted for around 25 minutes.

\section{Data Collection and Analysis}

The collected data were transcribed and analyzed by the research. In order to maintain the reliability of the coding, the researchers underwent the following coding process (Castleberry \& Nolen, 2018):

a) Conducting initial read through the text data

b) Divide into segments

c) Label with codes

d) Reduce and look for redundancy

e) Collapse codes into themes

In analyzing the data, thematic analysis was utilized to identify and develop emerging themes through proper coding approaches (Creswell \& Poth, 2016).

\section{RESULTS AND DISCUSSION}

\section{Results}

After conducting a careful analysis, the researchers found out that the codes were collapsed into 6 themes. Six main themes which emerged were to promote a system of thinking and learning, stimulate learners' engagements, enhance recognition of English language, self-regulated learning, learning resources and supports, and analyze students' prerequisites. Data saturation was achieved after 10 interviews and no information emerged.

Table 1

The table shows the characteristics of all the Study Participants $(n=10)$

\begin{tabular}{l|l}
\hline Characteristics & $18-21$ years old \\
\hline Age & All Female \\
Male/Female & College students \\
Educational Status & Universitas Advent Indonesia \\
School & Zoom \\
Web Platform & \\
\hline
\end{tabular}

Table 2

Table showing questions, relevant codes and emerging sub-themes pertaining students' perspective on PEBUC

\begin{tabular}{|c|c|c|}
\hline Question & Code & Sub-themes \\
\hline $\begin{array}{l}\text { How does your Lecturer introduce } \\
\text { important business terms before } \\
\text { explaining the topic? }\end{array}$ & 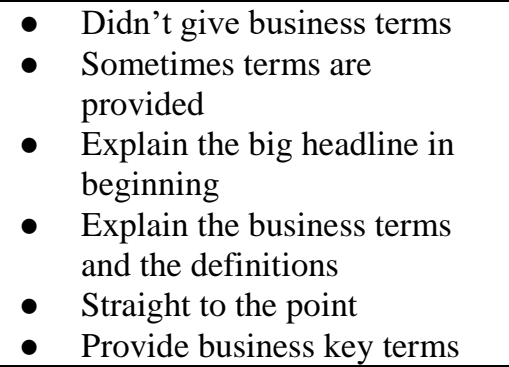 & \multirow[t]{2}{*}{ 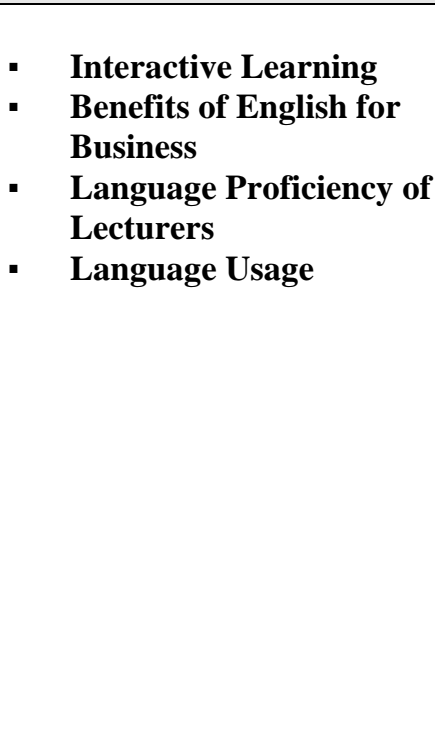 } \\
\hline $\begin{array}{l}\text { What is your opinion about the use } \\
\text { of English in business class? }\end{array}$ & $\begin{array}{ll}\text { - } & \text { Helpful for future } \\
\text { - } & \text { Help making business } \\
& \text { Make students more active in } \\
\text { - } & \text { Pring English } \\
\text { - } & \text { Won't lose in International } \\
& \text { trade competitive } \\
\text { - } & \text { Difficult due to limited } \\
\text { vocabulary }\end{array}$ & \\
\hline
\end{tabular}




\begin{tabular}{|c|c|c|}
\hline $\begin{array}{l}\text { What do you think about the } \\
\text { quality of your lecturer's English } \\
\text { proficiency in explaining the } \\
\text { material? }\end{array}$ & $\begin{array}{l}\text { - } \text { Fluent in English } \\
\text { - } \quad \text { Good pronunciation } \\
\text { - } \quad \text { The speech isn't halting } \\
\text { - } \\
\text { - } \quad \text { Language used is easy to } \\
\text { understand } \\
\text { - } \quad \text { Good delivering material } \\
\text { - } \\
\text { Detail and clearly } \\
\text { explanation }\end{array}$ & \\
\hline $\begin{array}{l}\text { Is your lecturer consistent in using } \\
\text { pure English as his/her medium of } \\
\text { instructions? }\end{array}$ & $\begin{array}{l}\text { - Use English to give } \\
\text { instruction about assignment, } \\
\text { PowerPoint slide, Moodle } \\
\text { Use Indonesian for a while } \\
\text { and then return to use } \\
\text { English } \\
\text { - Use Indonesian for the } \\
\text { important lesson } \\
\text { - Use pure English throughout } \\
\text { the end of the lecturer }\end{array}$ & \\
\hline
\end{tabular}

Table 3

Table showing questions, relevant codes and emerging sub-themes pertaining students' experience

\begin{tabular}{|c|c|c|}
\hline Question & Code & Sub-themes \\
\hline $\begin{array}{l}\text { How is your confidence in taking } \\
\text { the PEBUC program? }\end{array}$ & $\begin{array}{l}\text { - Afraid when the lecturer asks } \\
\text { Worry about being pointed or } \\
\text { asked because low English } \\
\text { proficiency } \\
\text { - Less able to understand } \\
\text { English } \\
\text { - Afraid can't answer when } \\
\text { asked by the lecturer } \\
\text { - Medium of instruction in } \\
\text { English } \\
\text { Don't feel anxiety because } \\
\text { quite understand } \\
\text { Worry during the exam, } \\
\text { afraid not understand the } \\
\text { exam questions }\end{array}$ & \multirow[t]{3}{*}{$\begin{array}{ll}\text { - } & \text { Technical Fields } \\
\text { - } & \text { Learning Challenges } \\
\text { - } & \text { Space for Language } \\
& \text { Development } \\
\text { - } & \text { Self-learning } \\
\text { - } & \text { Emerging Intrinsic } \\
& \text { Motivation }\end{array}$} \\
\hline $\begin{array}{l}\text { How has this PEBUC program } \\
\text { affected your English skills for } \\
\text { your future business career? }\end{array}$ & $\begin{array}{l}\text { Requirement for apply job } \\
\text { should be good at speaking } \\
\text { English } \\
\text { - Important role in the world of } \\
\text { business } \\
\text { Go everywhere should know } \\
\text { English } \\
\text { - Many companies led by } \\
\text { foreign boss } \\
\text { - Nowadays people use } \\
\text { English in doing business } \\
\text { International language }\end{array}$ & \\
\hline $\begin{array}{l}\text { How has this PEBUC program } \\
\text { triggered you to be more active in } \\
\text { using English? }\end{array}$ & $\begin{array}{ll}\text { - } & \text { Learn and dig more about } \\
\text { - } & \text { English } \\
\text { - } & \text { Trigluence in using English } \\
\text { meaning } \\
\text { - } \\
\text { - } \\
\text { - } \\
\text { Practice spesity learn English } \\
\text { Not active at outside } \\
\text { classroom because activities }\end{array}$ & \\
\hline
\end{tabular}




\begin{tabular}{|c|c|c|}
\hline & $\begin{array}{l}\text { aren't affected by using } \\
\text { English } \\
\text { - Require to use English in } \\
\text { class }\end{array}$ & \\
\hline $\begin{array}{l}\text { What aspect(s)/skill(s) of English } \\
\text { have improved during your } \\
\text { participation in the PEBUC } \\
\text { program? }\end{array}$ & $\begin{array}{ll}- & \text { Improved vocabulary } \\
\text { knowledge } \\
\text { - } & \text { More confident in speaking } \\
\text { English } \\
\text { - } \\
\text { - } \text { Geceive proper pronunciation } \\
\text { lecturer }\end{array}$ & \\
\hline $\begin{array}{l}\text { What are the things that motivate } \\
\text { you to keep pushing yourself to } \\
\text { comprehend the lessons in } \\
\text { English? }\end{array}$ & $\begin{array}{l}\text { Business lesson and English } \\
\text { are needed for the future } \\
\text { - } \begin{array}{l}\text { Important in Accounting } \\
\text { major }\end{array} \\
\text { - } \quad \text { Get low score if don't have } \\
\text { effort } \\
\text { - Already pay tuition fees } \\
\text { - The knowledge will be very } \\
\text { useful in the world of work } \\
\text { - Aspire to work in a foreign } \\
\text { company } \\
\text { English is standard language } \\
\text { for getting a job } \\
\text { Prepare for life in future }\end{array}$ & \\
\hline $\begin{array}{l}\text { How does your lecturer make this } \\
\text { PEBUC program a better place to } \\
\text { practice for international business } \\
\text { communication? }\end{array}$ & $\begin{array}{ll}\text { - } & \text { Make a promoting video } \\
\text { - } & \text { Make CV in English } \\
\text { - } & \text { Presentation in English } \\
\text { - } & \text { Required to use English } \\
\end{array}$ & \\
\hline $\begin{array}{l}\text { If you don't understand the } \\
\text { lessons, the use of terms, what } \\
\text { would you do? }\end{array}$ & $\begin{array}{l}\text { - } \\
\text { - } \\
\text { Afraid to ask } \\
\text { because mixed English- } \\
\text { Indonesian } \\
\text { - } \quad \text { Feel insecure } \\
\text { - } \text { Feel embarrassed because } \\
\text { people will see someone who } \\
\text { asking } \\
\text { - } \quad \text { Can't construct words } \\
\text { - } \text { Confused about the material } \\
\text { - } \text { Cond discussion } \\
\text { - } \text { Focabulary to grasp } \\
\text { - } \\
\text { Prefer to ask friend }\end{array}$ & \\
\hline
\end{tabular}

Table 4

Table showing questions, relevant codes and emerging sub-themes pertaining Program Development

\begin{tabular}{|c|c|c|}
\hline Question & Code & Sub-themes \\
\hline $\begin{array}{l}\text { How can this PEBUC program be } \\
\text { better? }\end{array}$ & $\begin{array}{l}\text { PEBUC program only } \\
\text { triggers students to use } \\
\text { English in class only } \\
\text { - The practice in class still in a } \\
\text { small or local scope not } \\
\text { prepared for international } \\
\text { business communication }\end{array}$ & \multirow[t]{2}{*}{$\begin{array}{ll}\text { - } & \text { Role of Lecturer } \\
\text { - } & \text { Teaching-learning } \\
\text { - } & \text { Development } \\
\text { - } \quad \text { English Language Learning } & \text { Supports } \\
\text { - } \quad \text { Separation English Level }\end{array}$} \\
\hline $\begin{array}{l}\text { How important is it to have } \\
\text { qualified lecturers in English }\end{array}$ & $\begin{array}{l}\text { The role of lecturer is still } \\
\text { very important and needed }\end{array}$ & \\
\hline
\end{tabular}


proficiency for the PEBUC program?
- Lecturer is role model and students' motivation

- Lecturer is one of source of learnings

- Students can emulate lecturer

- The medium of instructions in English

- Students are still in the process or learning stage of understanding English

How English is actually used for international business communication?

- Requirement use English in work or activities

- Go everywhere need English
- International language

- One of tools to communicate, to enter into the world of business

- Work not only with Indonesian

Do you think PEBUC programs will be better if the class separated based on students' English levels?

If separated

- Will not be more confident

- Knowledge will not be developed

- Demotivated to strive
How resources have been increased to support students' English language learning?

- English club to improve skill and knowledge

- More accustomed to use English

- English Day for one day a week to practice speaking English

- Games or quizzes in English or something that can make English learning more fun

- Confused about the material and discussion

needs of the students with limited English Vocabulary?
- A lot of new vocabulary make confuse

- Business lesson never known before

- Need to translate with Udictionary or Google Translate

\section{Results}

\section{Effectiveness of PEBUC Program}

The researchers then composed participants' perspectives into two emerging themes:

\subsection{Promote System of Thinking and Learning}

The PEBUC program is considered as a program that promotes a system of thinking and learning; it specifies learners' thinking ability. "Based on experience in Introduction to Business Class, in the beginning the lecturer gave any keywords that we will learn about business before entering the material. The keywords are in accordance with the material discussed," (Interviewee 10) "the business terms will be explained during the lesson," (Interviewee 9) "the lecturer gave the link about business terms and what things in the business world" (Interviewee 1). 
The researchers found out that the lecturer provided various examples to make the lessons easier to comprehend. "About marketing products, the lecturer gave examples so the lesson can be easier to understand," (Interviewee 6), "the lecturer explains about what are the things in our daily life and about lecturer's experience," (Interviewee 1) "the lecturer showed video related to the topic," (Interviewee 2). Besides providing examples, another interviewee said that, "the lecturer makes gestures and always uses simple words so the lesson can be easier to understand" (Interviewee 7). System approach to managing and applying knowledge is useful to accounting students. They were able to maintain their knowledge longer and develop a higher level of thinking skills (Duangploy \& Shelton, 2000).

\subsection{Stimulate Learners' Engagements}

Informants considered that PEBUC program stimulates learners' engagements in the use of English in Introduction to Business class. "English is really important because it is a world language. Everywhere we go, we should know English" (Interviewee 7). In addition, lecturer's language proficiency and language usage can also stimulate learning. "I really like when my lecturer explains the lessons, because she uses very simple words so that we can easily understand the lesson. The way she delivers the material is good and she speaks clearly" (Interviewee 3), "My lecturer is fluent in English, the pronunciation is good, and the speech is not halting" (Interviewee 6), "The quality of my lecturer is good, not stuttering, and the language used is easy to understand" (Interviewee 8).

"When the lecturer gives instructions about assignment, using slides, and Moodle, and everything is used in pure English. If the students really do not comprehend the lessons, the lecturer will use Indonesian for a while and then return to use English" (Interviewee 6 ), "the lecturer tries to get us to understand the lesson. If we don't understand, she will continue the lesson again with gestures" (Interviewee 7), "sometimes my lecturer will use Indonesian if there are students who don't understand and there's a very important thing which she wants to tell" (Interviewee 2). When learners could be active in learning and understanding the given feedback through questions and suggestions they can verify lessons they learn which provide deeper exploration (Schaaf et al., 2013).

\section{Engagement on English Learning}

The researchers composed participants' experience on PEBUC program into two emerging themes:

\subsection{Enhance Recognition of English Language}

The interviewees experienced that their English skills have improved during participation in the PEBUC program. Eight out of ten interviewees experienced enhancement in vocabulary knowledge, "Because every meeting has a new discussion, so we learn more new vocabulary" (Interviewee 6). Some of the interviewees also have improved in speaking skill, "because we have to use English to ask questions, so I become more confident in speaking English" (Interviewee 9). A few interviewees receive proper pronunciation, "previously I pronounce 'know' is now. So, I feel my pronunciation is more improved" (Interviewee 5). Another interviewee felt that, "I get used to listening when the lecturer explained in English. I can understand what other people say. But if I say it, I still feel difficult" (Interviewee 10). 
During their participation in PEBUC program, it triggers students more active in learning English. "With the PEBUC program, there will definitely be an influence in using English, but it depends on each student. For me, it triggers me to find out the meaning if I don't understand. If outside the classroom, sometimes I use English with friends who want to learn English too. If I use English with friends that don't want to learn English, they will tease me" (Interviewee 10), "I feel my English proficiency level is low, the day before Introduction to Business class, I will learn English harder so I will be more understanding. Because of the PEBUC program, my enthusiasm for learning and curiosity to learn English have increased" (Interviewee 2).

In Introduction to Business class, the interviewees shared the challenges they had. "If I want to ask, it should be in English. I can't construct words" (Interviewee 1), "I really feel anxiety even before the class. My English proficiency is low. So, I'm afraid I can't answer the question when the lecturer asked" (Interviewee 2), "I'm afraid of grammatical mistakes. Afraid of being laughed at because of that" (Interviewee 3), "I feel my vocabulary is very limited so I can't understand the explanation" (Interviewee 4), "I always feel worried when appointed or asked by the lecturer, because my English proficiency is low" (Interviewee 7), "I feel worried during the exam, afraid that I can't understand the exam questions" (Interviewee 10), "I'm afraid to ask. That time in English 1 class, when asking I mixed English-Indonesian, then I was laughed at by classmates and the lecturer. Even if that doesn't happen in Introduction to Business class, I never want to ask again" (Interviewee 6). It is important to make students realize that English is only a burden for them that are something beyond their approach. The learners are not passionate in learning because there is no healthy relationship between student and teacher (Ahmed et al., 2015).

\subsection{Self-regulated Learning}

In the PEBUC program, they have outcome expectations that can motivate them in learning, "I have to try to be the same as other friends who can speak English well. If I do not make an effort, my Introduction to Business score will be low. In the future, I aspire to work in a foreign company" (Interviewee 7), "even though the course is in English, I still have to get the knowledge. Because I pay tuition fees. Besides, the knowledge will be very useful in the world of work" (Interviewee 10), "nowadays, English is no longer a foreign language, but as the standard language for getting a job" (Interviewee 8), "I'm taking Faculty of Economy, Accounting, where my major is about Business world, finance, which leads to the international world. For future career, it is impossible to cooperate only with the Indonesians" (Interviewee 1). Zimmerman (cited in Alvi et al., 2016) stated three phases of learning: forethought, performance control, and self-reflection. Forethought phase is when learners set their learning goals. It involves task analysis and self-motivation. In task analysis, students make specific goals for learning and make a strategic plan to reach their goals.

William and Deci (cited in Lourenco \& Ferreira, 2019) said that a good learning climate can inspire students to establish autonomy in learning. "If I don't understand, I prefer to browser on Google" (Interviewee 7), If I don't understand, I prefer to use Udictionary" (Interviewee 1), "I better find out the lesson by myself than ask the lecturer" (Interviewee 4), "I studied before Introduction to Business class, so I can understand easily when the lecturer explains the lesson." (Interviewee 2), "I'd rather ask my friends than ask the lecturer. I prefer a friend's language because it is easier to understand" (Interviewee 8). 
In the PEBUC program, students experienced receiving various class activities from lecturers which somehow promoted self-regulated learning to do more exploration of the lessons. This is supported by the study of K \& Kurukkan (2016), which stated that when learners involve autonomy learning, they can help themselves attain learning objectives. "Lately, the lecturer asked us to make CV in English" (Interviewee 1), "the lecturer asked us to read aloud the lesson to know our speaking skill" (Interviewee 2), "We are required to give an opinion in English accordance with the questions given" (Interviewee 5), "In the class we are required to use English, such as question and answer" (Interviewee 9), "The lecturer gave us assignment to make video about promoting product-comparison of item $\mathrm{A}$ and item $\mathrm{B}$, promote the advantages and disadvantages" (Interviewee 6). Informants viewed all the given assignments as something reasonable.

\section{PEBUC Program Development}

\subsection{Learning Resources and Supports}

"It's really important having a qualified lecturer because the program is using pure English for the medium instruction. Also, students can emulate the lecturer" (Interviewee 8), "Lecturers who can speak English fluently may not necessarily be able to teach well when their students are still in the process or learning stage of understanding English. In my opinion, besides having lecturers who are good at English, lecturers who can teach or deliver material well are also needed" (Interviewee 9), "qualified lecturer is a role model. It is our motivation to have good English proficiency like the lecturer" (Interviewee 6), "if the lecturer isn't qualified, so the students will find it hard to understand the lesson" (Interviewee 2), "it's very important to support learning. If the English proficiency quality of the lecturer is good, students who receive the lessons can be easier" (Interviewee 3), "we can learn English more deeply from qualified lecturers. If the lecturers are less qualified, lecturers and students like still studying together" (Interviewee 4). The role of a lecturer as facilitator is fundamental to build strong knowledge in the field where knowledge is being transferred through mentoring (Yusof et al., 2020).

"PEBUC program only triggers students to use English in class only. Outside the classroom, we forgot to use English. The use of English the class is a bit boring when using English throughout the end of class. Because this class is all about material or theory, there is less interaction so it can make students sleepy" (Interviewee 9), "the practice in Introduction to Business class is still in a small or local scope. The use of English is still not prepared to reach out to international business communication. I think this program is practiced for local business, but the explanation uses English. The lecturer still does not consistently use pure English, sometimes still mixed EnglishIndonesian" (Interviewee 10).

\subsection{Analyze Students' Prerequisites}

Kucharcikova et al. (2019) stated that the essential element in the process of education is depending on the students themselves. The most important is their motivation for studying and for becoming a proficient master within specific needs of the practice. It is a prerequisite for successful achievement of expected results within the education process as well as for the sustainability of the process. Increase resources to support students' English language learning is needed, "so that we can be more accustomed to 
using English not only in Introduction to Business class" (Interviewee 7), "everyone has a different knowledge, so increase resources is very beneficial" (Interviewee 8), "maybe not all of them are interested in PEBUC program. I think it will be better if there are variations" (Interviewee 10), "Resources in English language learning at university are still lacking compared to other universities. So, it needs to be improved" (Interviewee $3)$.

Beside students giving opinions about why increasing resources to support students' English language learning is needed, they also provide advice about the English language learning supports. "I think the university can make English Club, but the teacher is native speaker. We already learn grammar and vocabulary in English 1 subject. But for me, the most important thing is improving the speaking in conversation and pronounce" (Interviewee 1), "university can make English Day practice speaking English. Because in class, we are usually the only listener" (Interviewee 2), "university can make games or quizzes in English. So, English learning will be more fun" (Interviewee 5), "the English debate competition can trigger students to actively use English" (Interviewee 9). The benefits of joining English club and participate in various language activities will give opportunity to take part in the national and international English competition; students will be able to develop their listening and speaking skills through formal and informal occasion, and have a chance to go abroad and learn different cultures (Yuliandasari \& Kusriandi, 2015).

In Introduction to Business Class, the class is not managed based on students' English level. It gives different atmosphere to students, "we will feel motivated to become more capable" (Interviewee 1), "we can learn more how to speak or communicate in English from friends who have not low English level" (Interviewee 4), "we can help each other" (Interviewee 3). If the class is separated by students' English level, "those whose English skills are low will not be more confident" (Interviewee 6), "if separated may be good, but there is demotivation to strive because it is not balanced" (Interviewee 8).

In contrast, "I think it will be better if the class separated based on levels. Because everyone's abilities in English are different, some are fluent, some are still below average. If the class is like this, learners with Low English level will feel insecure, afraid of speaking wrong, and embarrassed. They would not dare to speak, what stood out is only active students" (Interviewee 10). Henceforth, program designers of PEBUC should conduct an analysis on students' prerequisites with a purpose to cater the needs of all students.

\section{Discussion}

The results showed that the PEBUC program provides academic experience for students; it promotes a system of thinking and learning. By shaping and developing the PEBUC program further, it may provide a better impact on the success of students in achieving English proficiency in business fields. Hopper \& Stave (2008) stated that the system of thinking plays a significant role to enhance students' learning abilities. The systems approach in the classroom promotes active learning and helps students develop critical thinking and problem solving skills. Moreover, this program can stimulate learners' engagements. "Engagement behaviors are responsive to teachers' and schools' practices, allowing for the possibility of improving achievement and attainment for students experiencing difficulties along the way" (Christenson et al., 2012, p.99). 


\section{CONCLUSION}

The findings of this study pointed out two themes emerged on how students perceived the program; those themes are Promote Thinking-learning system and Stimulate Learners' Engagement. Furthermore, there are two themes that characterize the experience of informants on the program; which are, Enhance recognition of English Language and Self-regulated learning. Meanwhile regarding the needs of program development there are two themes emerged: Learning Resources and Analysis on Students' Prerequisites. All themes emerged from obtained sub-themes. Conclusively, the findings of this study indicated that PEBUC program could definitely promote a system of thinking and learning which could engage learners in English learning; however, the program should undergo periodic development in order to fulfill learners' needs so that the process of learning can take place properly. This program can trigger students to use English not only in the class, it also helps prepare students for international business communication.

\section{ACKNOWLEDGMENTS}

First and foremost, praises to God, the Almighty for His bountiful blessings throughout the process of this research work. We would like to express our deep and sincere gratitude to the research contributors: key informants and school administrators for giving the opportunity to conduct this study and providing insightful thoughts throughout this research. The invaluable guidance throughout this study is a precious thing we could experience.

\section{REFERENCES}

Ahmed, M., Aftab, M., \& Yaqoob, H. (2015). Students' Motivation toward English Language Learning at Undergraduate Level. Advances in Language and Literary Studies, 6(3), 230 238. https://doi.org/10.7575/aiac.alls.v.6n.3p.230

Alvi, E., Iqbal, Z., Masood, F., \& Batool, T. (2016). A Qualitative Account of The Nature and Use of Self-Regulated Learning (SRL) Strategies Employed by University Students. Australian Journal of Teacher Education, 41(8), 40-59. https://doi.org/10.14221/ajte.2016v41n8.3

Bargiela-Chiappini, F., \& Zhang, Z. (2013). Business English. In B. Paltridge \& S. Starfield (Eds.), The Handbook of English for Specific Purposes (pp. 193-212). Wiley-Blackwell.

Benzie, H. J. (2010). Graduating as a "native speaker": International students and English language proficiency in higher education. Higher Education Research and Development, 29(4), 447-459. https://doi.org/10.1080/07294361003598824

Castleberry, A., \& Nolen, A. (2018). Thematic analysis of qualitative research data: Is it as easy as it sounds? Currents in Pharmacy Teaching and Learning, 10(6), 807-815. https://doi.org/10.1016/j.cptl.2018.03.019

Christenson, S. L., Wylie, C., \& Reschly, A. L. (2012). Handbook of Research on Student Engagement. In Handbook of Research on Student Engagement (Issue June 2012). https://doi.org/10.1007/978-1-4614-2018-7

Crawshaw, R. (1984). Information, awareness and context as factors in foreign language learning. British Journal of Language Teaching, 22(2), 67-73. https://doi.org/10.1017/s0261444800014609

Creswell, J. W., \& Poth, C. N. (2016). Qualitative Interview Studies: Learning Through Experience. In Foundations for Research (4th ed.). 
DeMarrais, K. (2004). Foundations for Research. In K. DeMarrais \& S. D. Lapan (Eds.), Foundations for Research (pp. 51-68).

Duangploy, O., \& Shelton, M. L. (2000). Using a Systems Approach to Develop Lifelong Learning Skills in Accounting for Business Combinations. Journal of Education for Business, 76(2), 81-86. https://doi.org/10.1080/08832320009599957

Hopper, M., \& Stave, K. A. (2008). Assessing the Effectiveness of Systems Thinking Interventions in the Classroom. 26th International Conference of the System Dynamics Society. https://digitalscholarship.unlv.edu/sea_fac_articles/200

Hu, J., \& Wu, P. (2020). Understanding English language learning in tertiary English-medium instruction contexts in China. System, 93. https://doi.org/10.1016/j.system.2020.102305

K, A. G., \& Kurukkan, A. (2016). Self-Regulated Learning A Motivational Approach for Learning Mathematics. International Journal of Education and Psychological Research, $5(3), 60-65$.

Kankaanranta, A. (2008). Business English Lingua Franca in intercultural (business) communication. Language at Work - Bridging Theory and Practice, 3(4), 28-38. https://doi.org/10.7146/law.v3i4.6193

Kankaanranta, A., \& Louhiala-Salminen, L. (2010). "English? - Oh, it's just work!": A study of BELF users' perceptions. English for Specific Purposes, 29(3), 204-209. https://doi.org/10.1016/j.esp.2009.06.004

Köksal, D., \& Tercan, G. (2019). English as medium of instruction and international posture: From the perspective of students. Journal of Language and Linguistic Studies, 15(1), 362375. http://www.jlls.org/index.php/jlls/article/view/4/5

Koondhar, M., Elizabeth, M. A., Siming, I. A., \& Umrani, T. H. (2018). Language Learning Approaches : Unity in Diversity. Advances in Language and Literary Studies, 9(6), 3437. https://doi.org/dx.doi.org/10.7575/aiac.alls.v.9n.6p.34them

Kucharcikova, A., Miciak, M., Malichova, E., Durisova, M., \& Tokarcikova, E. (2019). The Motivation of Students at Universities as a Prerequisite of the Education's Sustainability within the Business Value Generation Context. Sustainability, 11(20). https://doi.org/10.3390/su11205577

Lauder, A. (2008). the Status and Function of English in Indonesia: a Review of Key Factors. Makara Human Behavior Studies in Asia, 12(1), 9. https://doi.org/10.7454/mssh.v12i1.128

Lourenco, D., \& Ferreira, A. I. (2019). Self-regulated learning and training effectiveness. International Journal of Training and Development, 23(2), 117-134. https://doi.org/10.1111/ijtd.12149

Low, P. (2020). An Investigation of English Usage in Careers of Thai Graduates with a Business Administration Degree. Shanlax International Journal of Education, 9(1), 27-32. https://doi.org/10.34293/education.v9i1.3416

Macaro, E. (2018). English Medium Instruction. In Studi e ricerche (pp. 15-20). https://doi.org/10.14277/6969-227-7/SR-13-1

Macaro, E. (2020). Exploring the role of language in English medium instruction. International Journal of Bilingual Education and Bilingualism, 23(3), 263-276. https://doi.org/10.1080/13670050.2019.1620678

Palinkas, L. A., Horwitz, S. M., Green, C. A., Wisdom, J. P., Duan, N., \& Hoagwood, K. (2015). Purposeful Sampling for Qualitative Data Collection and Analysis in Mixed Method Implementation Research. Administration and Policy in Mental Health and Mental Health Services Research, 42(5), 533-544. https://doi.org/10.1007/s10488-013-0528-y

Peters, H. (2014). Global English online - a case study of a distance learning course in a business context. Language and Literacy, 16(1). https://doi.org/10.20360/g28300

Pritasari, A., Reinaldo, H., \& Watson, C. W. (2018). English-medium instruction in Asian 
business schools : a case study. Journal of Multilingual and Multicultural Development, 1-13. https://doi.org/10.1080/01434632.2018.1458855

Sankar, G., \& Suresh Kumar, S. P. (2016). English for Employability and Empowerment- a Study. 4(July), 100-103. https://doi.org/10.14662/IJELC2016.053

Sari, F. M., \& Wahyudin, A. Y. (2019). Undergraduate students' perceptions toward blended learning through instagram in english for business class. International Journal of Language Education, 3(1), 64-73. https://doi.org/10.26858/ijole.v1i1.7064

Schaaf, M. Van der, Baartman, L., Prins, F., Oosterbaan, A., \& Schaap, H. (2013). Feedback Dialogues That Stimulate Students ' Reflective Thinking. Scandinavian Journal of Educational Research, 57(3), 227-245. https://doi.org/10.1080/00313831.2011.628693

Simmons, E. S. (2016). Eyes that See and Ears that Hear: A Case for Qualitative Research. International Forum, 19(2), 28-46.

Talaue, F. G., \& Kim, M. K. (2020). Investigating the advantages of english medium instruction (EMI) in the indonesian workplace. LEARN Journal: Language Education and Acquisition Research Network, 13(2), 321-334.

Tsou, W., \& Kao, S.-M. (2017). Overview of EMI Development. In W. Tsou \& S.-M. Kao (Eds.), English as a Medium of Instruction in Higher Education (pp. 3-20). https://doi.org/10.1007/978-3-319-51976-0_8

Yuliandasari, A., \& Kusriandi, W. (2015). Students' Perception on English Club Extracurricular in Speaking Practices at Madrasah. ELT Perspective, 3(2). https://doi.org/10.33603/perspective.v3i2.1670

Yusof, N., Awang-Hashim, R., Kaur, A., Malek, M. A., Shanmugam, S. K. S., Manaf, N. A. A., Yee, A. S. V., \& Zubairi, A. M. (2020). The role of relatedness in student learning experiences. Asian Journal of University Education, 16(2), 235-243. https://doi.org/10.24191/AJUE.V16I2.10308 